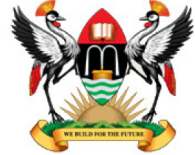

East African School of Higher Education Studies \& Development
Makerere Journal of Higher Education

ISSN: 1816-6822; 4(1) (2012) 1 - 10

DOI: http://dx.doi.org/10.4314/majohe.v4i1.1

(C) The Author(s) 2012

Reprints \& permission: EASHESD

http://ajol.info/majohe

\title{
Age as a Correlate of Quality of Academic Programmes: the Case of Public Universities in South West Nigeria
}

\author{
Bolupe Awe ${ }^{1}$ \\ ${ }^{1}$ National Open University of Nigeria [E-mail: bolawe1 @ yahoo.com]
}

\begin{abstract}
This study examined the influence of age on quality of academic programmes in South West Nigerian universities. A descriptive survey design was used in the study. Data were collected from 600 academic staff using stratified, purposive and simple random techniques. The data were analysed using frequency counts, percentages, means, standard deviation and t-test statistic. The study revealed that there was significant difference between first generation and third generation universities in their extent of compliance with quality assurance measures on academic programmes. Also, a significant difference was found between first generation and third generation universities on constraints to quality assurance measures with third generation universities facing greater constraints. It was recommended that both categories of universities be given adequate attention in the provision of quality-enhancing inputs. However, third generation universities should be accorded greater priority in allocation of resources. In addition, greater collaboration is recommended between first and third generation universities while newly established universities must be affiliated with older universities for mentoring.
\end{abstract}

Keywords: Age of University; Quality assurance; Programme accreditation

\section{$1 \quad$ Introduction}

The significance of university education in Nigeria is probably responsible for the interest shown by various governments in this sector of the educational system. For example, until 2000 all universities in Nigeria were owned either by the Federal or state governments. The Federal Government has always linked the establishment of its universities with National Development Plans and various administrations in Nigeria appear to have recognised the pivotal role of university education in national development.

The National Universities Commission (NUC) is yet to come up with an appropriate classification of Nigerian universities. However, historical 
evolution of Nigerian universities allows for classification along the variable of age. For example, when the Federal Military Government in 1972 took control of university education from state (region) governments, regional universities such as University of Nigeria Nsukka, the University of Benin, University of Ife and Ahmadu Bello University became Federal universities. These universities, in addition to the existing Federal Universities (i.e. University of Ibadan and University of Lagos) were the six Federal universities in existence as at August 1975 and constitute what is now referred to as first generation universities.

The Third National Development launched in September 1975 led to the creation of seven additional universities, namely, University of Calabar, University of Jos, University of Maiduguri, University of Sokoto, University of llorin, University of Port Harcourt, Bayero University that constitute what is tagged the second generation universities in Nigeria. However, with the introduction of 1979 Constitution, the Federal Government lost absolute control of universities, a development that led to creation of state universities in Nigeria. Subsequently, additional universities of technologies were created by various governments both Federal and states. The unfettered freedom to state governments through the 1979 Constitution allowed for the proliferation of universities in Nigeria. Further development in the Nigerian university system is the incursion of private entrepreneurs. As at the first quarter of 2012, Nigeria has 122 universities with ownership pattern as follows: 36 Federal universities, 36 state universities and 50 private universities. For the purpose of this paper, all Nigerian universities in existence between 1979 and 2001 are regarded as third generation universities. It is observed that mode of emergence of universities in Nigeria could have implication on quality of their academic programmes.

The beginning of university education in Nigeria was the establishment of University College as an affiliate of the University of London in line with the traditional British practice of special relationship with London. Following this trend, second generation Federal universities started as affiliates of older first generation universities. Ukeje (1992) observed that Universities of Ilorin, Kano and Port Harcourt were initially established as University Colleges under special relationship with the older first generation universities at Ibadan, Zaria and Lagos respectively. He went further to describe this as a return to the old British Tradition of special relationships, that is, the new in the old. This type of arrangement that allows the universities to evolve rather than emerge allows newly established universities to undergo a period of tutelage before attaining maturity. This period of gestation could possibly aid new universities to establish appropriate structures required for the smooth operation of a university. This consideration must have informed the decision of the Federal 
Government of Nigeria to affiliate some of the recently licensed universities with older universities.

However, state universities that came on board as from 1979 did not go through this gestation period and as such might lack necessary experience for building a solid academic and administrative structure for effective and efficient running of a university system. This could possibly translate to a situation where quality of academic programmes is constrained. On the contrary, third generation universities could exhibit better quality assurance measures learning from the experience of first generation universities. Therefore, it should be interesting to know whether disparity exists in quality between first generation and third generation universities.

In addition to acquisition of experience during the period of association with older universities, the economic situation at the period of establishment of universities could also impact on their quality. For instance, Adelabu (1992) observed that the more economically developed or wealthier a nation is, the greater the chances that its political regime will be supportive of strong civil libertarian policies such as free education. It is observed that universities in existence during the 60 s and early 70 s are likely to enjoy more benefits from government because of the robust economy. This situation may contrast sharply with what obtains when the nation's economy began to witness steady decline towards the end of 1979. Ogunade and Alani (1998) observed that the introduction of the Structural Adjustment Programme and the attendant inflationary effect as a result of devaluation of the Nigerian Naira accounted for huge increase in educational expenditure with no remarkable influence on educational services.

The number of universities in existence may likely have implication on the performance of these universities. This might be because these universities will be competing for the same resources. For instance the first generation universities were just six in number as at 1975, but with the creation of additional universities thereafter, there is likely to be a steady decline in the amount of resources allocated to them. For example, Aminu (1986) criticised the establishment of Federal Universities of Technology in view of their huge capital outlay when existing universities are begging for survival. He went further to suggest that some of the Federal Universities of Technology that are not viable should be shut while State Universities are generally not viable and would tend to become centres of mediocrity.

Reports of various accreditation exercises conducted by the NUC appear to indicate disparity in the performance of Nigerian universities. The NUC (2006) observed a structural imbalance in the distribution of academic staff. It was observed that most first generation universities have adequate staff compliment at the professorial level while the general trend was a bottom heavy staff structure. For example, in the case of Lecturer 1 and below, the observed figure 
for first generation universities was $58.4 \%$ as against recommended figure of $45 \%$. In the case of state universities, they were all reported to be bottom heavy and that over $70 \%$ of state universities have their academic staff being Lecturer 1 category or lower and that in some departments the head is a Lecturer Grade II (NUC, 2006). The outcome of the 2005 accreditation exercise further revealed disparity in the performance of these universities. While the six first generation universities had the least number of programmes with denied accreditation status, the state universities have most of their programmes under interim or denied accreditation status.

In a study conducted by Arubayi (1982) cited in Efoghe (2000) his findings identified age of university among other variables as affecting academic quality in the universities.

South West Nigeria happens to have the highest concentration of universities in Nigeria but not a single second generation university is cited in this geopolitical zone. In addition, second generation universities took off as affiliates of first generation universities unlike third generation universities that were not attached to any university before attaining autonomous status. It is in the light of this that this study was conducted to examine whether age of university could exercise any significant influence on the quality of academic programmes in the Nigerian university system. Therefore, only first and third generation universities that are located in the zone will be the focus of this study.

\subsection{Purpose of the Study}

The purpose of this study was to find out the influence of age on the quality of academic programmes in South West Nigerian universities. In terms of age, the study investigated whether there is disparity in quality of academic programmes between first and third generation universities. In addressing the problems of this study, the following research questions were raised:

1. Is it likely that the age of universities will influence their compliance with quality assurance measures for academic programmes?

2. Is it likely that age of universities will influence the constraints to quality assurance measures for academic programmes?

\subsection{Hypotheses}

The following hypotheses were generated to guide the study.

1. There is no significant difference between first and third generation universities in terms of compliance with quality assurance measures on academic programmes. 
2. There is no significant difference between first and third generation universities in terms of constraints to quality assurance measures on academic programmes.

\section{$2 \quad$ Methodology}

The descriptive design of the survey type was used in the study. The population of the study consisted of all the academic staff in South West Nigeria. Academic staff were considered as appropriate population since they occupy a crucial position on matters pertaining to development and delivery of academic programmes in universities. The sample comprised 600 academic staff with multistage sampling technique used to select the sample. At the first stage, the universities were stratified along the variables of age, that is, first generation and third generation. Four universities were randomly selected; this comprised 2 first generation universities and 2 third generation universities. At the second stage, simple random sampling technique was used to select 150 lecturers from each of the sampled universities.

A self designed questionnaire tagged Quality Assurance Questionnaire "QAQ" was used to elicit information from the subjects. The instrument comprised three sections, A-C. Section A was for personal information of the respondent such as name of institution, ownership, year of establishment, type of institution, qualification of respondent, sex, age, years of experience in the university, rank of respondent and department.

Section B had 18 items designed to determine the level of compliance with the control measures for high standard of academic programmes by the universities with the response options "Very Adequate" (4); "Adequate" (3); "Inadequate" (2) and "Very Inadequate" (1). The 18 items were clustered into 8 items. In addition, the response options of "Very Adequate" and "Adequate" were merged under adequate while "Inadequate" and "Very Inadequate" were merged under Adequate. Section C consisted of 18 items designed to determine constraints to control measures for high standard of academic programmes in the universities with the response options "Strongly Agree" (4); "Agree" (3); "Disagree" (2) and "Strongly disagree" (1). The 18 items were clustered 8 into items. The responses options of "Strongly Agree" and "Agree" were merged under Agree while responses options of "Disagree" and "Strongly disagree" were merged under Disagree

The data collected were analysed using frequency counts, percentages, means, standard deviation and t-test. All the hypotheses formulated were tested at 0-05 level of significance. 


\section{$3 \quad$ Results}

\subsection{Compliance with Quality Assurance Measures}

Scores of compliance with quality assurance measures for high standard of academic programmes were used to respond to research question one. The average scores under various control measures were computed and used to analyse the responses. The results are presented in Table 1.

Table 1: Compliance with Quality Assurance Measures

\begin{tabular}{lllll}
\hline \multirow{2}{*}{ Items } & ADEQUATE & \multicolumn{3}{c}{ INADEQUATE } \\
& Frequency & $\%$ & Frequency & $\%$ \\
\hline Admission requirements & 378 & 69 & 168 & 31 \\
Funding & 160 & 29 & 386 & 71 \\
Physical facilities & 134 & 25 & 412 & 75 \\
Quality of academic staff & 250 & 46 & 296 & 54 \\
Quality academic programmes & 380 & 69 & 166 & 31 \\
Self appraisal & 336 & 62 & 210 & 38.5 \\
External monitoring & 347 & 64 & 199 & 36 \\
Mean & 284 & 52 & 262 & 48 \\
\hline
\end{tabular}

Table 1 revealed the extent of compliance with control measures on quality assurance for academic programmes in the South West Nigeria universities. Sixty nine percent of the respondents indicated that compliance with admission requirements was adequate while $29 \%$ considered funding as adequate. Twenty five percent of the respondents considered physical facilities as adequate with $46 \%$ indicating the quality of academic staff as adequate. Sixty nine percent of the respondents considered the quality of academic programmes as adequate with $62 \%$ indicating self appraisal as adequate. Sixty four percent of the respondents considered compliance with external monitoring as adequate.

The result shows that on the average, 52\% of the respondents scored compliance with quality assurance measures as adequate. Generally compliance with quality assurance measures was adequate but inadequate on funding, physical facilities and quality of academic staff out of the seven categories of control measures under consideration.

\subsection{Constraints to Quality Assurance Measures}

Scores of constraints to quality assurance measures for high standard of academic programmes were used to respond to research question two. The 
average scores under various control measures were computed and used to analyse the responses. The results are presented in Table 2 .

Table 2: Constraints to Quality Assurance Measures

\begin{tabular}{lllll}
\hline \multirow{2}{*}{ Items } & \multicolumn{2}{c}{ AGREE } & \multicolumn{3}{c}{ DISAGREE } \\
& Frequency & $\%$ & Frequency & $\%$ \\
\hline Funding & 457 & 84 & 89 & 16 \\
Physical facilities & 463 & 85 & 83 & 15 \\
Lack of instructional aids & 489 & 90 & 57 & 10 \\
Inadequate library facilities & 439 & 80 & 107 & 20 \\
Personnel & 338 & 62 & 208 & 38 \\
Student crises & 268 & 49 & 278 & 51 \\
Political interference by Government & 414 & 76 & 132 & 24 \\
Administrative problems & 311 & 57 & 235 & 43 \\
Mean & 430 & 79 & 116 & 21 \\
\hline
\end{tabular}

Table 2 shows various constraints to control measures on the quality of academic programmes in South West Nigeria universities. Eighty four percent of the respondents agreed that funding was a constraint while $85 \%$ agreed that lack of physical facilities was a constraint. Ninety percent of the respondents agreed that lack of instructional aid was a constraint with $80 \%$ indicating library facilities as constraint. Sixty two percent of the respondents identified personnel as constraints while $49 \%$ indicated students' crises as constraint. Seven six percent of the respondents agreed that political interference from government was a problem with $57 \%$ agreeing that there were administrative problems.

The result reveals that on the average $79 \%$ of the respondents agreed that there were constraints to control measures on quality of academic programmes in South West Nigeria universities. The major constraints to control measures include funding, physical facilities, lack of instructional materials, inadequate library facilities, personnel and political interference from government. However, when these constraints are categorised, some disparities were noticed. Generally, all the respondents agreed that the universities were having constraints on quality assurance measures for academic programmes. 


\subsection{Testing of Hypotheses}

Hypothesis 1: There is no significant difference between first and third generation universities in terms of compliance with quality assurance measures.

Table 3: Difference in Mean Scores on Compliance with Quality Assurance Measures between First and Third Generation Universities

\begin{tabular}{llllllll}
\hline Group & N & Mean & SD & Df & t cal & t table & Result \\
\hline First generation & 129 & 49.92 & 8.35 & 544 & 4.98 & & \\
Third Generation & 417 & 46.11 & 7.38 & & & 1.96 & Significant \\
\hline
\end{tabular}

$\mathrm{p}<0.05$

Table 3 shows that $t$ cal (4.98) is greater than t table (1.96). Hence, the null hypothesis is not accepted. Therefore, there is significant difference in the level of compliance with quality assurance measures for academic programmes in the first and third generation universities. The mean for first generation universities (49.92) is greater than the mean score of 46.11 recorded for third generation universities. This implies that that there is better compliance with control measures on high standard for academic programmes in first generation universities than third generation universities.

Hypothesis 2: Age of universities will not significantly influence constraints to quality assurance measures.

Table 4: Difference in Mean Scores on Constraints to Quality Assurance between First and Third Generation Universities

\begin{tabular}{llllcll}
\hline Group & N & Mean & SD & Df & t cal & t table \\
\hline First Generation & 129 & 78.31 & 13.27 & 544 & 6.55 & \\
Third Generation & 417 & 86.31 & 11.75 & & & 1.96 \\
\hline
\end{tabular}

$\mathrm{p}<0.05$

Table 2 shows that $\mathrm{t}$ cal (6.55) is greater than t table (1.96). The null hypothesis is not accepted. Therefore, there is significant difference in the constraints to quality assurance measures for academic programmes in the first and third generation universities. The mean score for first generation universities (78.31) is less than the mean score of (86.31) recorded for third generation universities. This implies that first generation universities faced lesser constraints on quality assurance measures for academic programmes than third generation universities. 


\section{Discussion}

The result of hypothesis 1 indicated that there was significant difference between first and third generation universities in their compliance with quality assurance measures. The mean for first generation universities is higher than third generation universities. This implies that first generation universities exhibit greater compliance with quality assurance measures than third generation universities. This might not be unconnected with availability of enduring structures for quality assurance measures in first generation universities.

The implication of this is that the disparity in the extent of compliance with quality assurance measures could translate into variation in the quality of academic programmes offered by the two categories of universities in Nigeria. This in turn might lead to a situation where graduates from Nigerian universities exhibit different skills in the labour market. This could possibly lead to discrimination against graduates from the third generation universities in the labour market with its attendant negative image problems on third generation universities. This could impact negatively on the morale of undergraduates and graduates from the third generation universities. This supports Aminu (1986) and NUC (2006) about the poor performance of third generation universities comprising universities of technology and state universities. It also corroborates Efoghe (2000) that identified age of universities as one of the variables affecting quality of universities.

The result of hypothesis 2 revealed that there was significant difference between first and third generation universities on the constraints to quality assurance measures. Third generation universities have higher mean than first generation universities. The implication of this is that third generation universities are experiencing greater constraints to quality assurance measures than the first generation universities.

This might be due to the fact that third generation universities came into existence during the period of economic depression, unlike first generation universities that were established when universities were well funded and fewer in number. Thus the economic advantage of the first generation universities over their third generation counterparts could translate to lower constraints on quality assurance measures. The finding is supported by Adelabu (1992); Oguntoye and Alani (1998) and NUC (2006) that associated perceived decline in the quality of academic programmes in Nigerian universities to inadequate funding. 


\section{Conclusions and Recommendations}

Age was a factor in the extent of compliance with quality assurance measures among South West Nigerian Universities. In addition age of universities made a difference in constraints to quality assurance measures among these universities. It is therefore recommended that third generation universities should be given special attention to eliminate the obvious disparity between them and first generation universities. Such special attention could be in the area of adequate funding and provision of physical facilities.

In addition, newly established universities must be assigned to designated older universities in the same geo-political zone for mentoring while greater collaboration in the area of peer review must encouraged in order to acquire best experience in quality assurance measures on academic programmes.

\section{References}

Adelabu, M. A. (1992). Education policy making and implementation in an era of economic recession: The Nigerian case. In: Ipaye B. (Ed.) Education in Nigeria, past, present and future. Lagos: Macmillan Nigeria Publisher Limited. Pp. 170-176.

Aminu, J. (1986). Quality and stress in Nigerian education. Zaria: Northern Nigerian Publishing Company.

Efoghe, H. O. (2000). Quality of resourcing, staff and academic plan implementation in Federal and State universities. Journal of Teacher Education and Teaching. 4(1); 85-96.

NUC (2006a). How did Nigerian university system fare in 2005? Most stable and most productive in twelve years. Monday Memo, January, 5(1).

NUC (2006b). State universities in 2005: Fair performance on limited proprietor funding. Monday Memo. January, 5(2).

NUC (2006c). Results of the November 2005 system -wide accreditation exercise. Monday Memo, January, 5(3).

Oguntoye, A. O., Alani A. A. (1998). Financing education in Nigeria: Theory and Practice. llaro: Kinsbond Investment Limited.

Ukeje, B.O. (1992). Nigerian education: Unity within diversity, the old within the new. In: Ipaye B. (Ed.) Education in Nigeria, past, present and future. Lagos: Macmillan Nigeria Publisher Limited. Pp. 1-23. 